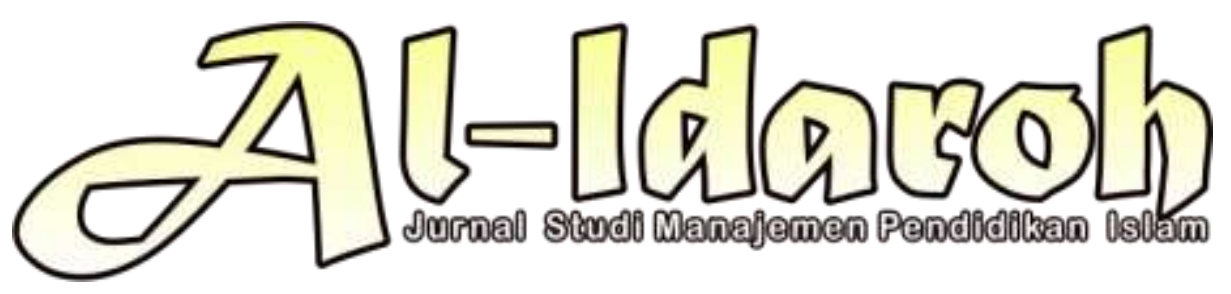

\title{
FILOSOFI MANAJEMEN PENDIDIKAN ISLAM DALAM PERSPEKTIF AL-QUR'AN
}

\author{
Mira Marisa \\ Madrasah Ibtidaiyah Al-Adli Palembang \\ Program Magister Manajemen Pendidikan Islam, UIN Raden Fatah \\ Email: miramarisa97@gmail.com
}

\begin{abstract}
Humans are creatures who have a great sense of curiosity. In its history, bumans are creatures who do not stop to philosophize, which in essence is that human beings will always seek a truth. Especially how bumans are able to manage their own thoughts. relating to humans who will not be separated from the problem of their thinking, this is related to the study of philosophy. Study of philosophy or philosophy in which it connects scientific terms, such as ontology, epistemology and axiology. Of course this is a conversation in which in the three terms, the three of them have different opinions regarding truth research. For this reason, with his thoughts, bumans are expected to be able to study various perspectives on scientific research. This research uses library research method, namely library research. With data collection techniques based on reading and writing results from several references such as books, journals and so on. Science from time to time will continue to carry out civilization. It can be seen clearly how the developing field of science gives rise to a plan and movement with the goals to be achieved. The field of science in question is the management of Islamic education. In the perspective of the Al-Qur'an, the management of Islamic education is related to how the forms of cooperation in managing and carrying out tasks in an institution are in line with an Islamic view.
\end{abstract}

Keywords: Philosophy, Islamic Education Management, Al-Qur'an Perspective 
Filosofi Manajemen Pendidikan Islam dalam Perspektif Al-Qur'an

\section{Pendahuluan}

Manusia telah diberikan oleh sang pencipta dengan memiliki sebuah naluri yang berbeda dari makhluk lainnya. Manusia memiliki rasa ingin tahu yang begitu tinggi. Hal ini diwujudkan dengan adanya berbagai upaya untuk memperoleh ilmu pengetahuan. Untuk memperoleh hal yang sedemikian rupa, manusia memerlukan cara dengan mengkaji ajaran-ajaran agama melalui filsafat.

Akhir abad ke-19 muncullah sebuah pandangan yang berkaitan dengan kelemahan positivisme, hal ini untuk upaya untuk mengungkap fenomena berupa sosial budaya masyarakat. Kebenaran dalam filsafat begitu dianggap penting. Hal ini dikarenakan filsafat diartikan sebagai pemikiran yang bijaksana dan cinta akan lingkungan. Aritoteles seorang tokoh filsuf yunani yang termahsyur begitu menghormati seorang gurunya yakni Plato. Filsafat dikatakan sebuah pemikiran yakni ilmu praktis dalam mendorong supaya akal manusia diharapkan dapat berpikir secara kebenaran atas peristiwa-peristiwa yang terjadi.

Kajian filosofis tidak akan terlepas dengan kaitanya akan istilah ontologi, epistemologis, dan aksiologi. Karena katiganya merupakan hakikat dari sebuah kemunculan istilah riset. Riset memiliki peran kontribusi dengan pemahaman terhadap suatu kejadian serta proses yang dialami. Sebuah riset akan memunculkan sikap kritisi didalam diri manusia terhadap apa yang menjadi saran dalam meningkatkan kualitas individu.

Seiring dengan berjalannya peradaban dunia dalam kajian filsafat ilmu, maka hal ini berpengaruh dengan perkembangan ilmu pengetahuan. Kondisi ini menjadi sorotan penuh bagi cendikiawan terutama umat Islam. Ilmu yang saat ini sedang pesatnya diperbincangkan yakni ilmu manajemen pendidikan. Kajian ilmu ini membahas sebuah materi yang didalamnya menyebutkan mengenai perencanaan, pengkoordinasian, pengorganisasian, pengaktualisasian, pengawasan. Beberapa hal tersebut penting perannya dalam pengelolaan sebuah lembaga, terutama lembaga pendidikan Islam.

Dinamika ilmu manajemen pendidikan senantiasa berkembang dengan peradaban dunia yang semakin terukir. Ilmu manajemen pendidikan merupakan sebuah ilmu yang diciptakan, dikembangkan serta dimanfaatkan guna untuk memajukan pendidikan, khususnya lembaga pendidikan Islam. Dalam ilmu 
pengetahuan dibutuhkan sebuah pengelolaan agar tercipta sebuah lembaga dengan tujuan yang diharapkan. Hal ini semestinya dijadikan sebagai satu konsep dasar Islam dalam mengintegrasikan berbagai ilmu pengetahuan apapun yang dipelajari oleh umat Islam.

Dalam ajaran agama ada dua wahyu sebagai jalan untuk memperoleh ilmu pengetahuan. Dua diantaranya tersebut ialah pengetahuan yang diperoleh melalui akal yang diberikan Allah sebagai bahan pemikiran dan pengetahuan yang diturunkan sebagai petunjuk bagi manusia dalam mengetahui kebanaran. Agar konsep tersebut bisa dicapai serta sejalan dengan apa yang diajarkan dan tertuang dalam Al-Qur'an. Sebagaimana firman Allah.

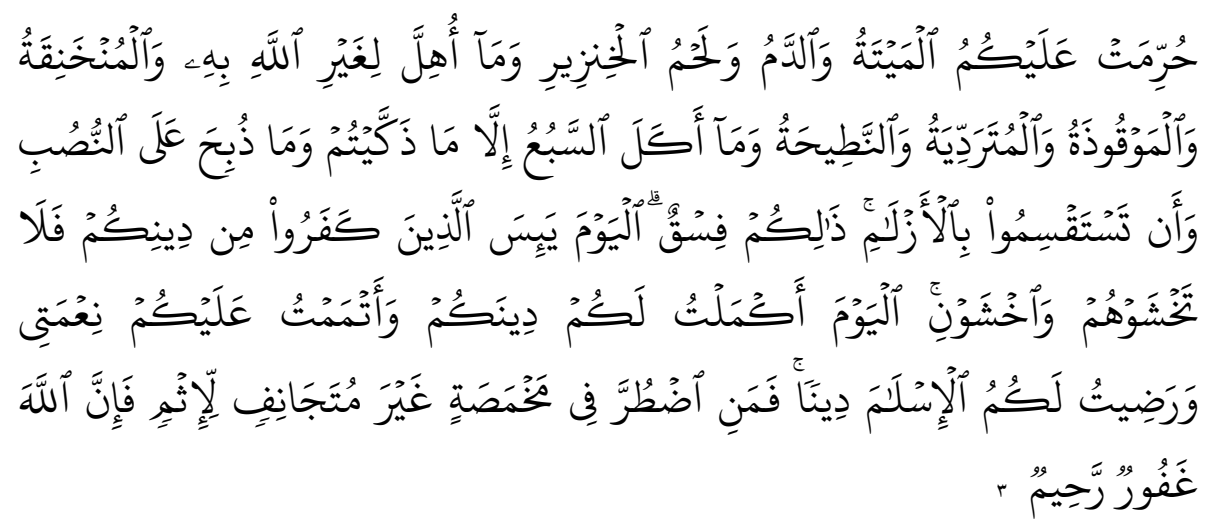

Artinya: "Diharamkan bagimu (memakan) bangkai, darah, daging babi, dan (daging) hewan yang disembelih bukan atas (nama) Allah, yang tercekik, yang dipukul, yang jatuh, yang ditanduk, dan yang diterkam binatang buas, kecuali yang sempat kamu sembelih. Dan (dibaramkan pula) yang disembelih untuk berhala. Dan (diharamkan pula) mengundi nasib dengan ąlam (anak panab) karena itu suatu perbuatan fasik. Pada hari ini orang-orang kafir telah putus asa untuk. (mengalabkan) agamamu, sebab itu janganlah kamu takut kepada mereka, tetapi takutlah kepada-Ku. Pada hari ini telah sempurnakan agamamu untukmu, dan telah Aku cukupkan nikmat-Ku bagimu, dan telah Aku ridai Islam sebagai agamamu. Tetapi barang siapa terpaksa karena lapar bukan karena ingin berbuat dosa, maka sungguh Allah maha pengampun maha penyayang". (Q.S. Al-Maidah: 3).

Dari ayat diatas, Allah SWT. telah memberitahukan kepada para hambanya melalui kalimat yang didalmnya menjelaskan larangan memakan bangkai-bangkai yang diharamkan. Diantaranya, yaitu hewan yang mati dengan sendirinya tanpa melalui proses penyembelihan ataupun pemburuan. Hal ini diharamkan karena mengandung mudarat. Namun, diantara bangkai tersebut dikecualikan untuk ikan, hal ini dikarenakan ikan tetap halal baik mati disembelih ataupun penyebab lainnya. 
Oleh sebab itu, semestinyalah sebuah ilmu pengetahuan dimuat sebagai prinsip-prinsip ajaran Islam dengan tujuan agar manusia lebih terarah dalam mengembangkan dan menerapkan ilmu pengetahuan dalam semangat ketauhidan. Sementara itu beberapa dugaan mengenai ilmu manajemen bahwa hal ini dikembangkan oleh dunia barat, akan tetapi disisi lain ilmu manajemen dikembangkan oleh adanya peradaban Islam. Beberapa tokoh yang dianggap sebagai pemikir ilmu manajemen pendidikan dalam Islam yakni Khulafa Al-Rashidin (632661M), Al-Faraby (870-950M), Al-Mawardi (972-1058 M), Al-Ghazali (1058-1111 M) dan Ibnu Khaldun (1332-1395 M). Dari beberapa tokoh tersebut tentunya memiliki perbedaan mengenai ilmu manajemen pendidikan Islam.

Memperhatikan berbagai konsep serta pemikiran yang berkaitan dengan ilmu manajemen pendidikan Islam, maka harus dilakukan pengkajian yang begitu mendalam dengan tujuan agar informasi yang diperoleh memiliki titik kesatuan yang kokoh dalam perkembangan zamannya hingga mencapai titik kejayaan Islam pada masa itu.Jenis data dalam penelitian ini berupa data kualitatif dengan menggunakan pendekatan library research (studi kepustakaan). Teknik pengumpulan data yang dilakukan yaitu dengan cara ke perpustakaan mengumpulkan berbagai referensi dari buku serta bahan tertulis lainnya dari beberapa referensi-referensi yang relevan. Dengan demikian, artikel ini membahas adanya urgensi ilmu manajemen pendidikan Islam dalam perspektif Al-Qur'an.

\section{Pembahasan}

A. Konsep Dasar Filsafat Manajemen Pendidikan Islam

Filosofi berasal dari kata "philoshopia" bahasa Yunani, diartikan sebagai "mencintai kebijaksanaan". Dalam bahasa Inggris kata filsafat disebut dengan istilah "philosophy" sedangkan dalam bahasa Arab diistilahkan dengan kata "falsafah" yang artinya "cinta kearifan". Dari uraian ini, dapat disimpulkan bahwa makna dari filosofi cinta akan kebijaksanaan. Sedangkan orang-orang yang berusaha mencari akan kebijaksanaan disebut sebagai filsuf atau filosof.

\footnotetext{
${ }^{1}$ Masyitoh, Filsafat Ilmu (Jakarta: PT. Bumi Aksara, 2011), 1.
} 
Manusia adalah makhluk yang memiliki rasa keingintahuan dimana pun dan kapan pun. Oleh sebab itu, terdapat letak perbedaan kebudayaan yang mana sedikit ataupun banyak mempengaruhi sebuah jenis kuantitas dan kualitas dari setiap individu. Setiap manusia dipengaruhi beberapa faktor, salah satunya faktor lingkungan. Filsafat bersumber dari manusia, maknanya bahwa manusia baik akal dan kalbu selalu berusaha untuk mencari suatu kebenaran dan memperoleh kebenaran.

Akan tetapi, adakalanya manusia mencari sebuah kebenaran didasari atas pengalaman yang terjadi pada dirinya. Hal ini tentu bukan merupakan suatu kegiatan ilmiah yang seutuhnya. Namun, bagaimana bentuk dari usaha itu sebenarnya. Usaha itu dilakukan dengan menggunakan beberapa metode yang bertujuan untuk menganalisa dan menghasilkan titik temu yang diharapkan. Manusia akan selalu bertanya mengenai suatu hakikat yang ada dalam diri manusia itu sendiri. Dalam artian, pada diri setiap manusia akan bermunculan pertanyaan (apa, bagaimana, dan mengapa). Oleh sebab itu, manusia akan berusaha untuk mencari serta memperoleh jawabannya dan pada saat itulah manusia dikatakan sedang berfilsafat.

Filsafat ilmu pada dasarnya merujuk kepada sebuah proses dan metode yang bertujuan untuk memperoleh pengetahuan secara ilmiah. Dalam hal ini, ilmu pengetahuan diperoleh dengan upaya sadar melalui tahap yang terdiri dari metode prosedur yang kebenarannya dapat diuji. Metode ilmiah merupakan sebuah proses terjadinya kegiatan yang membangun ilmu pengetahuan dari pengetahuan yang bersifat prailmiah dan sistematis mengikuti aturan prosedur penelitian ${ }^{2}$.

Dalam hal pengembangan ilmu pengetahuan manusia yang bersumber dari pemberitahuan maupun pengalaman hal ini tentu erat kaitannya dengan rasa keingintahuan dari manusia itu sendiri. Tentunya dengan kejadian tersebut, membuat manusia memaksakan dirinya untuk terus berpikir dan menjawab rasa keingintahuannya. Setiap manusia memiliki kemampuan dalam mengembangkan pengetahuannya, hal ini dikarenakan kemampuan yang dimilikinya inilah membuat manusia mengikuti progress dari perkembangan ilmu pengetahuan.

2 T. Erwinsyahbana, Penelitian Kualiatif Bidang Ilmu Hukum Dalam Perspektif Filsafat Konstuktivis, (Fakultas Hukum Universitas Muhammadiyah Sumatera Utara, 2017), 91. 
Sebuah kebenaran hanya bisa didapat dengan dua cara, yakni secara ilmiah dan non ilmiah ${ }^{3}$. Berkaitan dengan ini, maka sebuah penelitian dan ilmu pengetahuan tidak bisa dipisahkan satu sama lainnya. hal ini disebabkan karena pengetahuan berasal dari upaya mencari kebenaran yang dilakukan dengan pendekatan epistemologi dan harus dipertanggungjawabkan hasil dari kebenaran tersebut.

Menurut Maufur, pengetahuan merupakan sesuatu yang diketahui dan dipahami atas dasar kemampuan berpikir. Maufur juga mengatakan bahwa pengetahuan merupakan keseluruhan ide yang terkandung dalam pernyataanpernyataan yang dibuat mengenai suatu gejala atau peristiwa, baik itu yang bersifat alamiah, sosial, ataupun individual. Artinya, untuk ini pengetahuan secara dasarnya merupakan keseluruhan penjelasan dan gagasan yang terkandung pada sebuah pernyataan yang erat kaitannya dengan sebuah peristiwa disertai fakta didalamnya. Dari sisi perspektif sains, kebenaran diperoleh melalui proses penyelidikan dengan menggunakan metode ilmiah ${ }^{4}$. Dengan kata lain bahwa kebenaran menurut sains diperoleh dari hasil pencarian dan penemuannya dilakukan dengan cara empiris untuk menarik sebuah kesimpulan. Pada intinya bahwa kebenaran itu dapat ditemukan dengan logis dan empiris.

Manusia pada akhirnya harus tunduk pada pola-pola pengetahuan yang sifatnya universal, karena manusia akan terus dipengaruhi oleh lingkungan. Logika dari sebuah pemikiran yang ilmiah mencakup garis besar ide ataupun gagasan secara ketat dengan menerapkan prinsip nomotetik dan menggunakan pola edukatif. Pola dari nomotetik sendiri dimaksudkan ketarkitan antara suatu gejala sosial dengan gejalan sosial lainnya. Sedangkan, jika dari pola edukatif bahwa pemikiran dikembangkan dalam sebuah penelitian didasari pola yang sifatnya universal mengarah pada pola spesifik atau khusus.

Dalam penemuan ilmiah, hal ini didasarkan pada karakteristik keilmuan yang terdiri dari rasionalitas, empiris, dan sistematis.

\footnotetext{
${ }^{3}$ Gde Indra Bhaskara, "Penggunaan Metedologi Studi Kasus; Filosofi, Metodelogi Dan Metode," t.t., 31.

${ }^{4}$ Juliana Batubara, "Paradigma Penelitian Kualitatif dan Filsafat Ilmu Pengetabuan dalam Konseling," Jurnal Fokus Konseling 3, no. 2 (26 Agustus 2017): 95, https://doi.org/10.26638/jfk.387.2099.
} 
a. Rasional, yakni sebuah penyelidikan ilmiah yang dilakukan dengan masuk akal serta terjangkau oleh penalaran manusia.

b. Empiris, diyakini sebagai sebuah cara tertentu yang dapat diamati orang lain dengan menggunakan panca indera manusia.

c. Sistematis, yaitu proses disertai dengan langkah atau tahapan yang bersifat logis 5 .

Berdasarkan uraian diatas, maka ketika topik pembahasan yang dikaji mengenai filosofi (filsafat) erat kaitannya dengan istilah, ontologi, epistemologi, dan aksiologi. Sebuah ilmu pengetahuan akan terus dikaitkan dengan kamajuan riset. Dan hakikat dari riset itu sendiri adalah mencari, membuktikan serta menguji kebenaran guna membangun ilmu pengetahuan. Dalam artian yang sedemikian rupa, ontologi riset akan berbanding lurus dengan hakikat ilmu pengetahuan. Oleh sebab itu, ketika keduanya berbanding lurus maka, ontologi riset dapat dikatakan sebagai sebuah kebenaran. Berdasarkan uraian diatas, maka ruang lingkup filsafat ilmu mencakup berbagai disiplin ilmu yang terus berkembang, termasuk didalamnya yaitu ilmu manajemen pendidikan Islam.

Berbagai kritikan yang terjadi dalam manajemen pendidikan yang sifatnya sekular yakni bahwa manajemen pendidikan merupakan bagian dari ilmu pengetahuan. Namun, hal ini dibatasi dengan adanya proses pencarian kompetensi dalam mencapai tujuan dari sebuah lembaga khususnya lembaga pendidikan. Mengapa demikian, sebab hal itu hanya dibatasi dengan akal dan tidak memperhitungkan satu poin utama yakni kehidupan manusia. Ilmu bukanlah satu kesatuan yang letak diantaranya mengetahui dan diketahui, namun ilmu merupakan kesatuan dari keselurahan konsep mengetahui dan diketahui. Hal ini dikonstruksi oleh rohani atau jiwa dari berbagai objek yang diterima inderanya dalam iluminasi dari Allah. Dengan kata lain, bahwa adanya makna dari jiwa ke dalam jiwa untuk menunjukkan Allah adalah sumber pengetahuan, sedangkan hadirnya jiwa merupakan sebuah penafsiran yang terjadi. Oleh sebab itu, konsep dan ilmu manajemen merupakan salah satu bagian dari ilmu pengetahuan yang ada di dunia, kemudian berkembang dan terealisasikan oleh dunia barat, dan oleh

${ }_{5}$ M.P. Muhajirin, Pendekatan Praktis “Metode Penelitian Kualitatif Dan Kuantitatif”, (Yogyakarta: Idea Press, 2017),6. 
karena itu seharusnyalah hal ini dapat mengindahkan islamisasi dari ilmu pengetahuan.

Namun demikian, manajemen pendidikan dalam perspektif Islam mengakui bahwa hal itu sebagai bagian dari ilmu pengetahuan barat. Dengan catatan asal tidak bertentangan serta tidak melemahkan aqidah Islam, maka hal ini bisa untuk dipergunakan dan dijadikan sebagai bahan pertimbangan. Ada sebuah kutipan dari Ibnu Rushd yang mengatakan, yaitu:

Seandainya bangsa asing sudah menguasai ilmu tersebut (filsafat), maka sudah menjadi kewajiban yang jelas terhadap kita (muslim) agar mempelajari dan mengambil manfaat dari apa yang sudah mereka kuasai, terlepas apakah bangsa tersebut beragama Islam ataupun tidak. Kita harus membaca buku-buku mereka, meneliti dan menilai apa saja yang dapat dijadikan teori. Seandainya apa yang dijelaskan itu benar, kita menerimanya, dan sebaliknya apabila keliru kita menolak ${ }^{6}$.

Manajemen pendidikan dengan sebuah pendekatan sistem serta proses yang saat dipelajari pada prinsipnya sama, namun ada beberapa bagian dari itu menjadi sebuah perbedaan yang terletak dalam konsep manajemen itu sendiri. Kromkowski mengatakan bahwa manajemen merupakan rangkaian proses dalam sebuah pencapaian dengan tujuan organisasi yang dilakukan melalui empat tahap penting dalam manajemen yakni perencanaan, pengorganisasian, pengarahan dan pengawasan.

George dan Jones mengatakan bahwa manajemen merupakan proses merencanakan, mengorganisasikan, mengarahkan serta mengawasi sumber daya dari organisasi tersebut dengan tujuan tercapainya sebuah organisasi yang efektif dan efisien. Kemudian, Stoner dan Wankel menjelaskan bahwa manajemen merupakan bagian dari proses perencanaan, pengorganisasian, memimpin, serta mengontrol dengan maksud agar anggota organisasi dapat memanfaatkan sumber sumber organisasi kemudian merealisasikannya sesuai dengan tujuan yang telah ditentukan dan dengan harapan dapat mencapai maksimal yang lebih baik ${ }^{7}$.

Namun demikian, ada juga yang menjelaskan bahwa manajemen sebagai konsep bagian dari seni yang bekerja melalui peran yang dimainkannya dan juga orang lain yang ikut andil dalam memainkan peran tersebut. Mengenai konsep

6 Siti Baroroh Barried, Pengantar Teori filologi, (Yogyakarta: Badan Penelitian dan Publikasi Fakutas, 1994), 89.

${ }^{7}$ R Terry George, Prinsip-Prinsip Manajemen, (Jakarta: Bumi Aksara, 2009), 23. 
barat bahwa mereka beranggapan konsep manajemen tidaklah bersifat universal. Akan tetapi, ditentukan kepada siapa dan dimana konsep dari manajemen itu dapat direalisasikan. Sebagaimana yang dikatakan oleh Naceur bahwa konsep manajemen konvensional adalah beragama, yang disimpulkan dari studi empiris yang didalamnya terdapat kerangka budaya ${ }^{8}$.

Dalam hal ini, perlu diadakannya telaah melalui studi yang kritis dengan beberapa jumlah konsep dan ilmu manajemen pendidikan yang sampai sejauh ini terus berkembang dan melahirkan model serta konsep manajemen yang selaras dengan tradisi, nilai budaya sekolah dan masyarakat dimana penduduk Indonesia mayoritasnya beragama Islam. Dengan demikian, pendekatan yang perlu diterapkan adalah pendekatan prinsip serta nilai-nilai yang sejalan dengan Islam.

Beberapa kasus yang terjadi di negara seperti Jepang dan Korea berhasil dalam manajemennya yang dipengaruhi oleh model serta konsep yang sesuai dengan nilai-nilai didalam masyarakatnya. Gaby A Mendoza menjelaskan bahwa nilai-nilai dalam manajemen dipraktikkan oleh orang Asia dan Amerika memiliki perbedaan karena nilai-nilai dari bangsa itu pun tidak sama9.

Oleh karena itu, sebuah analisa mengenai konsep manajemen pendidikan dalam paradigma Islam menukil paradigma dari Al-Faruqi yang mengatakan bahwa dikotomi antara akal dan wahyu tidak diterima oleh Islam. Oleh sebab pendapatnya tersebut, maka pertentangan antara akal dan wahyu ataupun sains serta agama tidak dapat diakui dalam Islam ${ }^{10}$. Selain itu, Al-Attas juga berpendapat bahwa sebagian dari keseluruhan konsep dasar Islam perlu diintegrasikan ke dalam sains apapun yang dipelajari oleh orang Islam, sehingga Islamisasi memiliki makna pelepasan dari unsur-unsur ideologi ${ }^{11}$. Persoalan ini, maka dalam sistem manajemen pendidikan Islam bisa dinilai sebagai satu konsep yang sejalan, terlepas hal itu berangkat dari peristiwa yang dialami manusia.

Manajemen pendidikan dalam perspektif Islam, tidak diungkapkan secara lebih jelas ataupun khusus dalam Al-Qur'an mengenai konsep manajemen pendidikan. Walaupun demikian, arti manajemen asal katanya adalah

${ }^{8}$ Didin Hafidudin, Manajemen Syariah Dalam Praktik, (Jakarta: Gema Insani, 2011), 19.

${ }^{9}$ Passmore John, A Hundred Years Of Philosophy, (Harmondsworth: Penguin, 1966), 5.

${ }^{10}$ Ibrahim Mahdi, Amanah Dalam Manajemen, (Jakarta: Pustaka Al-Kautsar, 2010), 9.

${ }^{11}$ Rumayulis, Ilmu Pendidikan Islam, (Jakarta: Kalam Mulia, 2008), 79. 
“yudabbiru"yang mengandung artian bahwa Allah telah mengurus, menetukan, dan mengatur segala urusan yang berkaitan dengan seluruh alam semesta ini dengan sempurna. Namun, walau tidak ada arti lebih khusus mengenai manajemen pendidikan, kata "yudabbiru" dalam bahasa Arab diartikan sebagai hal yang mengawal, mengatur, melaksanakan, mengurus, mengarahkan serta mengendalikan. Secara teoritisnya bahwa hal ini dalam perspektif Islam berkenaan dengan prinsip, nilai, serta fungsi harus ada dalam manajemen pendidikan yang bersifat eksplisit maupun implisit.

Fokus telaah kajian mengenai ilmu manajemen pendidikan adalah manusia. Hal ini terlihat bagaimana peran dari manusia itu sendiri. Manusia merupakan rumus dari sebuah konsep serta ilmu manajemen pendidikan dan juga bagian dari sasaran manajemen. Oleh sebab itu, dengan perannya manusia memiliki kemampuan dalam mengkritisi dalam ilmu manajemen pendidikan.

Allah telah menciptakan langit dan bumi untuk manusia serta diberikan amanah untuk bisa mengurus dan memakmurkan apa yang ada di bumi. Dalam perspektif Islam, ilmu manajemen telah diformulasikan oleh Barat, yang mana hal ini telah dipelajari dari waktu Rasulullah SAW hijrah kemudian mensyiarkan Islam ke umat manusia dengan penuh arti yang begitu tersurat dengan sebuah penjelasan dari konsep manajemen yang sampai saat ini dan selanjutnya akan terus berkembang. Oleh karena itu, bagi seorang manajer atau pemimpin ia perlu mempelajari bagaimana model dari sebuah kepemimpinan dari sosok Rasulullah SAW khususnya manajemen dalam Islam itu sendiri.

Beberapa hal yang menjadi pokok pemikiran dari konsep manajemen pendidikan, yaitu:

1. Eksplisitas

Tidak eksplisitnya sebuah prinsip dan nilai Islam dalam konsep ilmu yang terus berkembang akan memunculkan kritikan begitu besarbagi konsep dan ilmu manajemen pendidikan. Hal ini karena sejumlah pendapat para ahli, salah satunya Al-Attas yang menjelaskan konsep dasar Islam perlu diintegrasikan dalam ilmu pengetahuan apapun bentuk yang ia pelajari. Sehingga hal ini, mengandung artian bahwa islamisasi sebagai sebuah bentuk pembebasan ilmu 
pengetahuan dari interpretasi yang berlandaskan ideologi, atau hal yang bisa dikatakan bersfiat sekuler.

Berpacu dari pernyataan Al-Attas diatas artinya penting bagi muslim untuk memiliki ilmu pengetahuan khususnya konsep dan ilmu manajemen yang selaras dengan aturan Islam, yakni sebuah sains yang didasari atas prinsip Islam. Meskipun ada saja pendapat yang akan mengatakan bahwa ilmu pengetahuan bersifat netral yang tidak memihak suatu organisasi etnik (budaya) tertentu.

Lepas dari sebuah konsep manajemen pendidikan yang bersifat sekuler, maka yang terjadi adalah munculnya kritikan dari para pakar mengenai konsep dan ilmu manajemen pendidikan. Manajemen pendidikan yang secara tidak sadar berlandaskan sekularisme hanya akan berorientasi pada persoalan dunia. Beberapa hal yang berkaitan dengan ruang lingkup pendidikan akan mempertimbangkan nilai-nilai kehidupan yang ilahiyah serta non-ilahiyah.

Adanya pemisahan antara praktik dan teori dalam manajemen pendidikan hal ini berkaitan dengan teori Weber yang menjelaskan adanya pengaturan, hierarki serta pembagian prosedur yang didasari dasar birokrasi. Sedangkan dalam konsep konvensional, bahwa manajemen hal yang bersangkutan dengan perencanaan, pengorganisasi, motivasi dan pengawasan terlebih dalam lembaga pendidikan yang ekspektasi ataupun bentuk implementasinya adalah upaya pengoptimalan bagi kepuasan seorang konsumen yakni peserta didik dengan harapan peserta didik meraih keberhasilan pendidikannya yang bersih dan diridhai oleh Allah.

Kemudian, terlepas dari hal diatas bahwa manajemen konvensional dijadikan sebagai patokan untuk mengimplementasikan kemanfaatan materi. Hal tersebut, tentu akan membuat semuanya tidak terkendali. Karena, manajemen pendidikan dikatakan sebagai sebuah alat dan kegiatan. Dikatakan sebagai alat karena dapat membantu untuk berjalannya keberlangsungan hidup setiap individu. Selanjutnya dikatakan sebagai bentuk kegiatan, karena hal ini sebagai bentuk garis besar dari manfaatnya yang bersifat materi dan tidak didasari atas dasar syariah. 
Filosofi Manajemen Pendidikan Islam dalam Perspektif Al-Qur'an

2. Implisitas

Didasari faktor analisa yang sifatnya kritis maka pokok para gagasan konsep dan ilmu manajemen pendidikan, hakikatnya mempunyai makna adanya prinsip dan nilai Islam. Misalnya, pokok pemikiran yang menejalaskan bahwa bentuk produktivitas akan meningkat yang mana sebuah organisasi lebih memperhatikan kepentingan pegawai atau anggota dari organisasi itu sendiri. Hal ini sejalan dengan sebuah prinsip kemaslahatan. Seperti contoh, pokok pemikiran yang menjelaskan sebuah pekerjaan harus dilandasi oleh ilmu dan sebagainya. Hal ini perlu dimiliki dan dipahami serta diaplikasikan. Dalam firman Allah, yaitu.

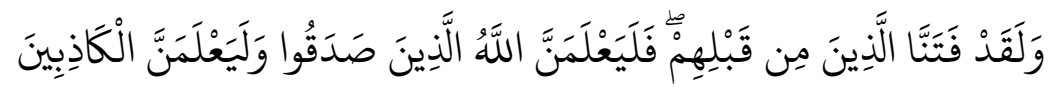

Artinya: "Dan perumpamaan-perumpamaan ini kami buat untuk manusia, dan tidak ada yang akan mamahaminya kecuali mereka yang berilmu". (Q.S. Al-Ankabut: 3).

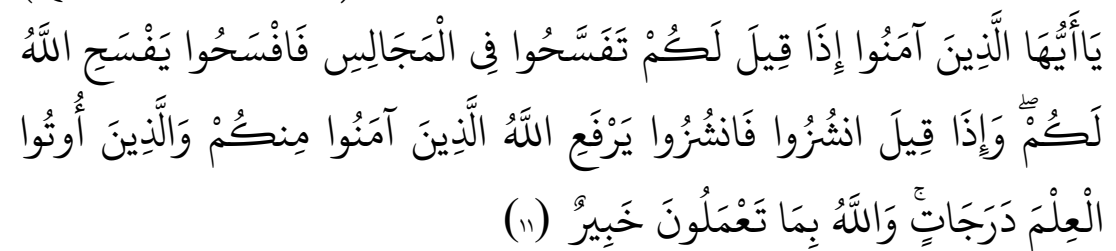

Artinya: "Wahai orang-orang yang beriman! Apabila dikatakan kepadamu "Berilah kelapangan di dalam majelis-majelis, "maka lapangkanlah, niscaya Allab akan memberi kelapangan untukmu. Dan apabila dikatakan, "Berdirilah kamu "maka berdirilah, niscaya Allah akan mengangkat (derajat) orang-orang yang diberi ilmu beberapa derajat. Dan Allah Maha mengetahui terhadap apa yang kamu kerjakan". (Q.S. Al-Mujadilah: 11).

$\mathrm{Hal}$ ini telah jelas bahwa Allah akan mengangkat derajat seorang hambanya bagi ia yang beriman dan berilmu. Dengan demikian, bahwa ilmu pengetahuan telah memberi pengaruh kontribusi bagi pemikiran setiap individu terutama dalam hal mengelola sebuah lembaga. Pokok bagian dari sebuah pemikiran tersebut diilustrasikan dengan keterlibatan seorang individu dalam sebuah lembaga yang perannya adalah seorang pegawai. Kemudian, ketika seorang pegawai memiliki prestasi, hal ini bentuk secara implisitnya akan diberikan sebuah reward. Secara implisit terdapat beberapa hal prinsip yang diterapkan dalam manajemen pendidikan salah satunya yakni as-syura yang maknanya adalah musyawarah. 
Syura merupakan sebuah kegiatan perbincangan dengan sejumlah orang dalam tujuannya untuk memecahkan persoalan-persoalanyang ada. Dalam AlQur'an syura dijelaskan sebagai sebuah prinsip dalam mengelola kehidupan yang didalamnya terdapat keputusan. Dalam firman Allah Q.S Ali 'Imran:159 "Maka berkat rahmat Allah engkau (Muhammad) berlaku lemah lembut terhadap mereka. Sekiranya kamu bersikap keras dan berhati kasar, tentulah mereka menjaubkan diri dari sekitarmu. Karena itu maafkanlah mereka dan mohonkanlah ampun untuk mereka, dan bermusyawaralah dengan mereka dalam urusan itu. Kemudian, apabila engkan telah membulatkan tekad, maka bertawakallah kepada Allah. Sungguh, Allah mencintai orang yang bertawakal'.

Dari ayat diatas bahwa syura dipandang sebagai sebuah konsep maupun prinsip yang dijadikan sebagai bahan pertimbangan. Hal ini didasari karena munculnya alasan dari sebuah pertimbangan yang mayoritas hasilnya lebih cenderung tepat. Selain itu, syura juga telah menjadi sebuah budaya dari kehidupan nabi Muhammad SAW. Tidak ada keputusan yang lebih baik tanpa sebuah diskusi ataupun perundingan. Nabi Muhammad dan para sahabat selalu bermusyawarah baik dalam apapun bentuk persoalan yang sedang dihadapi. Seperti contoh diantaranya yakni perang badar, perang uhud, dan sebagainya. Yang sedemikian rupa, banyak pokok pikiran dari ilmu manajemen pendidikan yang telah dikembangkan sebagai bahan sebuah pemikiran, karena ilmu manajemen pendidikan tidak lain dan bukan juga merupakan sebuah faktor dari hasil pemikiran seorang individu.

3. Komparasi Konsep Ilmu Manajemen Pendidikan

Tabel. 1

Konsep Ilmu Manajemen Pendidikan

\begin{tabular}{|l|l|l|}
\hline \multicolumn{1}{|c|}{ Elemen } & \multicolumn{1}{|c|}{$\begin{array}{c}\text { Manajemen } \\
\text { Pendidikan } \\
\text { Konvensional }\end{array}$} & $\begin{array}{c}\text { Manajemen } \\
\text { Pendidikan Islam }\end{array}$ \\
\hline Dasar & $\begin{array}{l}\text { Konsep hidup } \\
\text { dengan materialistik } \\
\text { duniawi. }\end{array}$ & $\begin{array}{l}\text { Ketauhidan, yakni } \\
\text { keseimbangan } \\
\text { antara dunia dan } \\
\text { akhirat. }\end{array}$ \\
\hline Tujuan & Keuntungan bersifat & Keuntungan \\
\hline
\end{tabular}




\begin{tabular}{|l|l|l|}
\hline & individualis. & didasari sikap sosial. \\
\hline Model & $\begin{array}{l}\text { Beragam tergantung } \\
\text { pada individu dan } \\
\text { kondisi. }\end{array}$ & $\begin{array}{l}\text { Syura yang } \\
\text { diselaraskan dengan } \\
\text { adaptable. }\end{array}$ \\
\hline Filosofi & $\begin{array}{l}\text { Kerja didasarkan } \\
\text { perahanan man material yang } \\
\text { dalam kehidupan } \\
\text { dunia kerja untuk } \\
\text { kepuasan diri. }\end{array}$ & ikhlas dengan tujuan \\
& ibadah. \\
\hline
\end{tabular}

Dari tabel diatas, dapat kita deksripsikan bahwa letak perbandingan dari manajemen pendidikan secara konvensional maupun konsep manajemen pendidikan Islam didasari atas emapat elemen yakni dasar, tujuan, model serta filosofi. Yang mana pada tabel diatas sudah terlihat jelas perbandingan dari elemen-elemen yang dimaksud.

B. Filosofi Manajemen Pendidikan Dalam Perspektif Al-Qur'an

Manajemen pendidikan Islam merupakan bagian dari konsep ruang lingkup pendidikan yang hakikatnya berasal dari manusia itu sendiri. Manusia secara fitrahnya merupakan seorang khalifah di muka bumi. Oleh sebab itu, bentuk pencapaian eksistensi dari manusia memiliki peranan yang sangat penting ${ }^{12}$. Dengan demikian, ketika pembahasan yang dilakukan adalah membahas sebuah konsep dari manajemen pendidikan maka tidak terlepas dari hasil pemikiran serta perilaku manusia itu sendiri. Semua bagian dari manajemen khususnya seorang manajer yang ikut andil, harus memiliki prinsip yang sejalan dengan ajaran Islam yakni syura atau musyawarah, amanah, serta bersikap adil.

Manajemen pendidikan Islam dalam Al-Qur'an tidak begitu tampak secara nyata dalam hal konsep, akan tetapi manajemen ditinjau dari akar kata "yudabbiru" yang memiliki makna bahwa Allah telah mengatur, menetapkan serta mengurus berbagai urusan yang kaitannya erat dengan alam semesta ${ }^{13}$. Hal ini tentu dikatakan sebagai bagian dari manajemen pendidikan Islam, karena sebenarnya hal tersebut telah ada saat sebuah sejarah telah lahir dari peradaban manusia.

${ }^{12}$ Hadari Nawawi, Administrasi Pendidikan, (Surabaya: CV. Haji Masagung, 2000), 78.

${ }^{13}$ M. Yatimin Abdullah, Studi Islam Kontemporer, (Jakarta: Amzah, 2006), 58. 
Konsep manajemen pendidikan dalam Islam telah ada semenjak kelahiran Islam itu sendiri, yakni ketika Nabi Muhammad SAW sedang berdakwah di kota Makkah. Seiring berjalannya zaman, manajemen pendidikan Islam terus berkembang ini terlihat dikala nabi hijrah ke kota Madinah dan disana beliau menegakkan pemerintahan Islam yang pertama kalinya. Artinya, kajian tentang manajemen pendidikan Islam ini telah dimulai sejak Nabi Muhammad SAW diutus menjadi seorang rasul, dengan alasan beliau merupakan seorang pionir dalam mengatur manajemen pendidikan. rasulullah sepanjang masanya akan selalu dijadikan panutan bagi pengikutnya sebagai seorang pemimpin karena sifat, sikap dan perbuatannya.

Begitu luas keteladanan dari seorang Nabi Muhammad SAW hingga memberi pengaruh besar dalam berbagai aspek kehidupan. Dengan demikian, pada hakikatnya bahwa mempelajari sejarah dari kisah seorang Rasulullah membawa sebuah konsepsional yang teramat menyentuh dalam mengukir hukum, kaidah serta prinsip. Hal ini menjadi sebuah kajian yang memiliki tujuan bahwa pada dasarnya hakikat Islam mengakui secara holistik keteladanan dari seorang Rasulullah seperti beliau.

Keteladan dari sosok Rasulullah membawa peradaban kehidupan, khususnya pada bidang pendidikan yang sangat membutuhkan peran seorang pendidik serta tenaga kependidikan dalam mengelola dan memperlakukan peserta didik sebagai individu yang harus tumbuh besar dari masa ke masa. Oleh sebab itu, pendidikan sudah seharusnya melakukan transformasi terlebih pada akhlaq serta nilai yang tidak hanya sebatas transfer of knowladge.

Sejarah menjelaskan bahwa dari sosok seorang Rasulullah, beliau telah menanamkan adanya sifat kasih sayang dalam kehidupan terlebih itu pun pada hal kepemimpinan. Hal ini terlihat jelas sebagaimana beliau berinteraksi, mendidik serta mampu memimpin umatnya. Sungguh tidak heran kalau kejayaan Islam dipegang oleh para tokoh yang memiliki kemampuan luar biasa. Seperi misalnya Salman Al-Farisi yang sukses menjadi seorang gubernur di Persia, terlebih sebelum itu ia hanya seorang yang mengenal dan mengetahui cara menanam sebuah pohon kurma di Madinah. Kemudian, seorang pengembala kambing yakni Abdullah bin Mas'ud yang berhasil menjadi seorang guru dan ahli tafsir Al-Qur'an. Berikutnya 
seorang Umar bin Khattab yang menjadi pemimpin negara begitu sulit untuk menemukan lawannya dan Khalid bin Walid yang juga menjadi seorang panglima perang.

Dengan demikian, artinya begitu besar pengaruh Rasulullah dengan segala sikap baiknya yang mampu dicontoh dalam banyak segi kehidupan. Rasulullah merupakan seorang anak yatim yang tidak memperoleh pendidikan formal yang mengajarkannya bagaimana cara membaca, menulis dan sebagainya. Namun, beliau sangat memfokuskan dirinya bagaimana pentingnya sebuah pendidikan agar mampu meningkat mutu yang ada pada setiap diri manusia. Sosok beliau pun ternyata tidak pernah sama sekali menerima sebuah pendidikan dari lembagalembaga pendidikan Yunani yang diperankan oleh filsuf-filsuf, akan tetapi pemikirannya mampu menangkap dan merespon banyak hal persoalan dari setiap manusia.

Namun, setiap manusia tidak ada yang seperti beliau. Hal ini karena begitu banyak sifat mulia yang ada pada diri Rasulullah. Selain itu, Rasulullah SAW pun mengalami berbagai macam problematika di kehidupannya. Terlebih beliau pernah mengalami begitu banyak harta kekayaan, yang sedemikian itu bahwa Rasulullah mengemban amanah pada dirinya untuk mampu memanfaatkan harta yang ia miliki dengan baik. Beliau pun menjadi seorang pemimpin pada berbagai bidang, oleh karena itu apa salahnya kita belajar untuk dapat mencontoh beliau.

Model manajemen pendidikan yang diperankan oleh Rasulullah SAW memiliki empat unsur, yakni tauhid (ibadah), amal shaleh, khalifah dan kesuksesan. Hal ini diupayakan agar manusia mampu memainkan perannya sebagai khalifah. Dari segi kepemimpinan dalam Islam, ada beberapa hal yang menjadi fokus penting mengemban tugas diantaranya adalah as-syura, keadilan, serta hak kebebasan dalam menyampaikan pendapat. Pada dasarnya bahwa dalam menjalankan ataupun melakasanakan tugas harus sejalan dengan nilai-nilai Islam, yakni diantaranya kewibawaan diri, peningkatan hubungan, efektifitas kepemimpinan, peningkatan moral dan cara pengelolaan yang beretika.

Oleh sebab itu, perlu dilakukan upaya untuk merealisasikan manajemen pendidikan Islam dalam mencapai tujuan. Dalam hal ini, berdasarkan paradigma tauhid yang dijadikan sebagai filsafat manajemen pendidikan atas dasar prinsip 
Islam, maka dalam menjalankan fungsi manajemen organisasi itu sendiri yakni seharusnya berasaskan pada amal ibadah serta bentuk kekhalifahan yang berpacu pada prinsip ajaran Islam. Yang sedemikian itu, sistem manajemen pendidikan harus bersifat komprehensif. Maksudnya adalah terintegrasi antara proses dan prinsip-prinsip ajaran Islam yang tidak merubah makna dari Islamisasi manajemen pendidikan.

Manajemen yang baik merupakan manajemen yang memenuhi syarat kriteria yakni ciri, falsafah, serta profesionalisme. Untuk mewujudkannya, maka ketiga dimensi yang dijadikan sebagai syarat kriteria tersebut menjadi sebuah perhatian khusus. Konsep dasar filsafat serta nilai yang ada pada manajemen pendidikan Islam tidak cukup menjadi sumber ataupun bagian dalam mempertimbangkan segala sesuatu yang berkaitan dengan manajemen. Namun, Al-Qur'an dan AsSunnah tetap menjadi bahan kajian dalam manajemen pendidikan Islam. Hal ini didasari atas adanya nilai kemasyarakatan maupun kemanusiaan yang terintegritas dalam satu kaitan yang tidak bisa ditumpang tindihkan dengan yang lainnya.

Kembali pada dasar model manajemen pendidikan bahwa konsep dari model tersebut menjadi pemicu dalam meningkatkan semangat Islamisasi ilmu pengetahuan dan terealisasinya paradigma dari barat mengenai konsep manajemen pendidikan. Oleh karena itu, perlu adanya pembahasan dalam memaknai konsep dari manajemen pendidikan Islam yang dari masa ke masa dunia barat terus berdatangan untuk memberi pengaruhnya ${ }^{14}$. Yang menjadi pokok utama dalam proses mengkaji hal tersebut yaitu aqidah, kepentingan manusia, kepentingan peradaban, dan kepentingan ilmiah. Empat kepentingan ini menjadi satu bagian yang erat dalam konsep manajemen pendidikan Islam.

Konsep manajemen pendidikan Islam dalam Al-Qur'an bahwa manajemen dikatakan sebagai bagian yang bersifat fleksibel, efektif, efisien, terbuka, kooperatif dan partisipatif. Mengenai hal ini, maka diuraikan sebagai berikut ${ }^{15}$.

a. Fleksibel

\footnotetext{
${ }^{14}$ Asep Kurniawan, "Filsafat Ilmu Manajemen Pendidikan Islam Rekontruksi Kritis Islamisasi Manajemen Pendidikan Islam Dalam Konteks Kekinian" 5, no. 1 (2019): 26.

${ }^{15}$ Amirudin, Manajemen Pendidikan Islam Perspektif Filsafat Ilmu dan Al-Qur'an, Program Pascarasarjana IAIN Raden Intan Lampung, 33.
} 
Arti kata dari fleksibel yakni tidak kaku. Menurut Imam Suprayogo bahwa berdasarkan pengamatan beliau walaupun sifatnya masih terbatas, hal ini menunjukkan sebuah lembaga sekolah atau madrasah meraih prestasi unggul dikarenakan pengelolaannya dalam menjalankan tugas. Kemudian, dari pada itu hal ini memberikan sebuah penjelasan yang dalam terhadap tata cara pengelolaannya sehingga memerlukan pengambilan keputusan yang sifatnya tegas dan bijaksana. Firman Allah mengenai fleksibilitas tercantum dalam Q.S Al-Hajj:78 "Dan berjibadlah kamu pada jalan Allah dengan jihad yang sebenarbenarnya. Dia telah memilih kamu dan dia sekali-kali tidak menjadikan untuk kamu dalam agama suatu kesempitan". Ayat tersebut telah menjelaskan bahwa Allah tidak akan menyempitkan kamu dari segala sesuatu yang tidak bisa kau lewati. Oleh sebab itu, tetaplah berpijak pada jalan kebenaran.

b. Efektif dan Efisien

Pekerjanan yang efektif adalah pekerjaan yang hasilnya memberikan dampak yang sesuai dengan rencana. Sedangkan dari sisi keefisiannya, pekerjaan yang mengeluarkan sebuah biaya namun tetap berjalan sesuai dengan rencana. Kedua kata baik efektif maupun efisien selalu bergandengan dalam manajemen pendidikan. Hal ini dikarenakan manajemen yang efektif bisa saja akan terjadi pemborosan. Sedangkan, manajemen yang sifatnya hanya efisien juga akan berdampak tidak tercapainya tujuan. Penjelasan mengenai efektif dan efisien terdapat dalam firman Allah Q.S Al-Kahf:26-27 yakni "Katakanlab: Apakah akan kami beritahukan kepadamu tentang orang-orang yang paling merugi perbuatannya. Yaitu orang-orang yang telah sia-sia perbuatannya dalam kehidupan dunia ini, sedangkan mereka menyangka bahwa mereka berbuat sebaik-baiknya”. Dari ayat tersebut telah dijelaskan bahwa orang yang sangat merugi kehidupannya didunia adalah mereka yang tidak memanfaatkan perbuatannya dengan baik, yang hanya duduk santai tanpa sebuah usaha. Dalam kaitan manajemen, hal ini menjelaskan bahwa ketika apa yang telah direncakan namun tidak berjalan sesuai dengan apa yang diatur maka hal ini akan sangat merugikan dan berdampak besar terkhusus lembaga pendidikan 
yang didalamnya terdapat orang-orang yang bekerja keras untuk mampu mencapai sebuah terget sesuai dengan tujuan yang hendak dicapai.

c. Terbuka

Kata terbuka yang dimaksud adalah tidak hanya hal yang berkaitan dengan informasi saja, namun mampu memberi serta menerima saran atau pendapat dari orang lain. Khususnya dalam manajemen pendidikan, tidak hanya seorang pemimpin yang mampu mengambil kuasa akan tetapi orang-orang yang terlibat dalam sebuah lembaga tersebut memiliki hak untuk menyampaikan pendapatnya. Al-Qur'an telah memberikan hak kepada setiap kaum muslimin agar berlaku jujur dan adil karena hal ini merupakan bentuk dari sebuah keterbukaan. Hal ini tercantum dalam firman Allah Q.S An-Nisa: 58 "Sesunggubnya Allab menyuruh kamu menyampaikan amanat kepada yang berhak menerimanya, dan (menyurub kamu) apabila menetapkan bukum di antara manusia supaya kamu menetapkan dengan adil. Sesunggubnya Allab memberi pengajaran yang sebaik-baiknya kepadamu. Sesunggubnya Allah adalah maha mendengar lagi maha melihat'.

d. Kooperatif dan Partisipatif

Dalam melaksanakan tugasnya seorang manajer dalam pendidikan Islam harus memiliki jiwa yang kooperatif dan partisipatif. Mengapa demikian, karena beberapa hal yang menyebabkan manajemen harus bersifat kooperatif dan partisipatif. Hal ini dikarenakan, dalam kehidupan kita tidak pernah bisa lepas dari keterbatasan. Q.S Al-Maidah: 2 "Bertolong-menolonglah kamu dalam berbuat kebajikan dan taqwa serta janganlah kamu bertolong-menolong dalam perbuatan dosa dan permusuban". Ayat tersebut menjelaskan bahwa, agar tercapainya sebuah tujuan pendidikan Islam maka perlu adanya seorang manajer atau pemimpin dalam pendidikan mampu membuat perencanaan, mengorganisir, menggerakkan serta melakukan kontrol dengan mengetahui sebuah kekuatan (strength), kelemahan (weakness), peluang (opportunity) serta ancaman (threat) yang mampu mengatur lembaga pendidikan Islan sesuai dengan apa yang tercantum dalam Al-Qur'an. 


\section{Filosofi Manajemen Pendidikan Islam dalam Perspektif Al-Qur'an}

Dengan demikian, dapat disimpulkan bahwa filosofi manajemen pendidikan Islam dalam perspektif Al-Qur'an mencakup berbagai hal baik dari bidang filsafat ilmu maupun disiplin ilmu dari manajemen pendidikan Islam. Oleh karena itu, sebuah filosofi erat kaitannya dengan berbagai pandangan yang memunculkan dan menghasilkan sebuah pemikiran, hal ini akan terus terjadi. Namun, kaitan dan bentuk penerapannya tetap harus selaras dengan apa yang telah tercantum didalam Al-Qur'an.

\section{Kesimpulan}

Filosofi merupakan bagian dari kerangka berpikir yang memiliki arti cinta akan kebijakasanaan. Filsafat dijumpai dengan pemikiran yang berlandaskan dengan istilah ontologi, epistemologi, dan aksiologi. Ketiga hal ini disinyalir dengan kaitannya dalam perkembangan sebuah riset dalam bentuk pembenaran. Riset dikatakan ilmiah apabila secara bentuk teori dan hasil telaahnya menghasilkan kesamaan. Perkembangan ilmu pengatahuan dari masa ke masa akan semakin terukir. Hal ini karena terjadinya sebuah peradaban. Saat ini dunia barat telah masuk ke ruang lingkup perkembangan ilmu pengetahuan, terkhusus dalam ilmu manajemen pendidikan Islam. Adanya pengaruh dunia barat dalam perkembanagan ilmu manajemen pendidikan Islam, tidak akan memutus eksistensinya bagaimana ilmu manajemen pendidikan akan tetap bertahan serta mampu merencanakan, mengorganisir, menggerakkan, dan memberikan kontrol yang baik. Dalam perspektif Al-Qur'an bahwa manajemen pendidikan Islam merupakan salah satu bidang ilmu yang memberikan dampak besar bagi sebuah lembaga dalam mencapai tujuan yang diharapkan. Tentu dalam mencapai tujuan tersebut diberlakukan kerjasama yang baik antar manajer atau pemimpin dan orang-orang yang terlibat didalamnya. Dengan demikian, bahwa filosofi manajemen pendidikan Islam dalam perspektif AlQur'an merupakan bagian dari sebuah pemikiran setiap manusia dalam mewujudkan sesuatu yang hendak dicapai. Namun, tetap berdasarkan pada aqidah keislamisasian manajemen pendidikan yang bentuk perencanaannya sesuai dengan tujuan pendidikan Islam. 


\section{Daftar Pusataka}

Amirudin, Manajemen Pendidikan Islam Perspektif Filsafat Ilmu dan Al-Qur'an, Lampung: Program Pascarasarjana IAIN Raden Intan Lampung, 2018.

Abdullah M. Yatimin, Studi Islam Kontemporer, Jakarta: Amzah, 2006.

Bhaskara, Gde Indra. "Penggunaan Metedologi Studi Kasus; Filosofi, Metodelogi Dan Metode," (2019), t.t.

Barried Siti Baroroh, Pengantar Teori filologi, Yogyakarta: Badan Penelitian dan Publikasi Fakutas, 1994.

Batubara, Juliana "Paradigma Penelitian Kualitatif dan Filsafat Ilmu Pengetahuan dalam Konseling," Jurnal Fokus Konseling 3, no. 2 (26 Agustus 2017): https://doi.org/10.26638/jfk.387.2099.

Erwinsyahbana, T. Penelitian Kualiatif Bidang Ilmu Hukum Dalam Perspektif Filsafat Konstuktivis, (Tesis Fakultas Hukum Universitas Muhammadiyah Sumatera Utara, 2017)

George R Terry, Prinsip-Prinsip Manajemen, Jakarta: Bumi Aksara, 2009.

Hafidudin Didin, Manajemen Syariah Dalam Praktik, Jakarta: Gema Insani, 2011.

John Passmore, A Hundred Years Of Philosophy, Harmondsworth: Penguin, 1966.

Kurniawan Asep, "Filsafat Ilmu Manajemen Pendidikan Islam Rekontruksi Kritis Islamisasi Manajemen Pendidikan Islam Dalam Konteks Kekinian” Volume 5, Nomor. 1 (2019)

Mahdi Ibrahim, Amanah Dalam Manajemen, Jakarta: Pustaka Al-Kautsar, 2010.

Masyitoh, Filsafat Ilmu Jakarta: PT. Bumi Aksara, 2011.

Muhajirin M.P, Pendekatan Praktis. Metode Penelitian Kualitatif Dan Kuantitatif, Yogyakarta: Idea Press, 2017.

Nawawi Hadari, Administrasi Pendidikan, Surabaya: CV. Haji Masagung, 2000.

Rumayulis, Ilmu Pendidikan Islam, Jakarta: Kalam Mulia, 2008. 